\title{
Novel Innovation of Subsidized Fertilizers Based on Soil Variability and Farmer's Perception
}

\author{
Elisa Wildayana, M. Edi Armanto, Imron Zahri and M. Yamin Hasan \\ Faculty of Agriculture, Sriwijaya University, South Sumatra Indonesia \\ Jalan Palembang-Prabumulih Km 32, Campus Indralaya (30662), South Sumatra \\ Phone 0711-820933 HP. +62-8127338950 \\ Corresponding Author: ewildayana@unsri.ac.id
}

Received: February 2017; Accepted: May 2017

\begin{abstract}
This paper aimed to find novel innovation and research of subsidized fertilizers based on soil nutrient variability and farmer's perception in rice farming. This study uses a completely randomized design with four natural treatments, a one-way Anova and Tukey HSD Test as well as multiple linear and cubic regressions. The fertilizer uniformity on varied ricefields was a big failure because it causes fertilization becoming ineffective, inefficient and unsustainable. Ricefield variability (due to geomorphogenesis, pedogenesis, interflow flow, vegetation distribution, land use patterns, and fertilizer application) causes not optimized fertilization (dose, balance, time, methods of fertilization). The perception of farmers can create conflicts of interest, which are determined as normal, unavoidable and natural. Shortterm research target is how fertilization in the field is done effectively, efficiently, and sustainably, whereas long-term target is to generate new sources of wealth, fertilization technology based on soil science knowledge, forming professional researcher, the great inventions of patents, cooperation media between scientists, technocrats and bureaucrats and research funding.
\end{abstract}

Keywords: Novel innovation, subsidized fertilizer, variability, perception, rice farming JEL Classification: O31, H24

\section{Introduction}

Achieving food security should be followed by appropriate and optimal policy in the agricultural sector. As we know that the low rice productivity is mostly caused by a lack of fertilization to rice, so the fertilizer play important function in increasing productivity, rice production and the income of farmers. Therefore, the government is required to make policy in managing the procurement and distribution of subsidized fertilizers to farmers. The fertilizer subsidy is motivated by the fact that most farmers are small farmers with limited capital, so that the fertilizer subsidy is expected to provide an outlet for farmers to get out of the poverty cycle, increasing food security and increasing the capacity and national production (Armanto et al., 2013; Rashid et al., 2013; Kariyasa et al., 2004).
The use of fertilizers is still low and not evenly distributed throughout the province of South Sumatra due to lack of access and the high cost of fertilizer (Wildayana, 2014; 2015). However the Government has provided subsidized fertilizer which tends to increase from year to year, but is not targeted to certain soil typology, soil variability and accessibility of certain infrastructure. The fertilizer subsidy recommendation is purposed for general soil condition (Wildayana et al., 2016; 2017; Ellis and Maliro, 2013). Appropriate information and facts regarding a specific natural conditions is very helpful to optimize fertilizer application (either dose, timing and type of fertilizer). If soil variability is taken into account, then the efficiency and effectiveness of the fertilizer subsidy will be achieved, effective, sustainably and to minimize environmental 


\section{Jurnal Ekonomi Pembangunan, 18 (1), 2017, 50-63}

pollution (Comtea et al., 2013; Banful, 2011; Warr and Yusuf, 2014).

Subsidized fertilizer has focused only on the macro elements only (e.g. NPK) which is the main limiting factors of plant growth, while the micro elements have not been entered to the category of subsidized fertilizer. There are some other factors affecting the efficiency of fertilizer use, among others, soil acidity and water management. Both these components are also important limiting factors, which are very difficult to be managed by farmers. Based on the limiting factors (soil acidity and water management), then agricultural land can be divided into two groups, namely responsive soils and non-responsive soils. Responsive soils will respond positively to given fertilizers (Urea and NPK fertilizers), otherwise nonresponsive soils are not able to respond to the treatment of fertilization due to its dominant limiting factors, namely soil acidity and water management (Ricker-Gilbert et al., 2009; Rachman and Sudaryanto, 2010). Variability of soil acidity and water management is not seriously attended by the Government and farmers have difficulty in managing these factors at a macro scale (Druilhe et al., 2012; Inoue et al., 2015; Osorio et al., 2011; Galperin and Viecens, 2017).

The results of agronomic trials on the rice farming for over 10 years proves that a rice plant responses low to fertilizer P. The soil conditions may respond poorly to fertilizer $\mathrm{P}$ unless their treatment prior to $\mathrm{P}$ fertilization is done, for example applying organic material and liming. In addition, high soil fertility will respond negatively to changes in soil fertility (the act of fertilization). Application of fertilizer for rice in the non-responsive soils is not able to improve agronomic or economic efficiency.

Responsive soils generally occur where major limiting factors in plant growth are nutrient deficiencies, especially macro soil nutrient. Fertilizer application on such soils will be very useful to increase rice yields and soil productivity. In the soils have also been an increase in fertilizer demand of about $5.0 \%$ per year, while the national fertilizer production stagnant at an average utilization of $75 \%$ of the capacity of the fertilizer needs. The need fertilizer for food crops is met only about 75$85 \%$ of the total fertilizer requirements of national and $15-25 \%$ for large enterprises, namely plantations and industrial (Rachman and Sudaryanto, 2010). There are no available data for non-responsive soils, although subsidized fertilizer needs are calculated on the basis of general soils without paying their soil variability.

The HET (the highest retail prices) of subsidized fertilizers in packs of $50 \mathrm{~kg}$ or $20 \mathrm{~kg}$ are purchased to farmers, growers, farmers, fishermen at authorized retailers in cash kiosk and distributors. The authorized retailers are obliged to ensure the availability of subsidized fertilizer when needed by farmers corresponding allocation has been determined. The implementation of the procurement, and the distribution of subsidized fertilizer are made in accordance with the provisions of regulation of the minister of trade on procurement and distribution of subsidized fertilizer for agriculture sector. The study aimed to find novel innovation and research of subsidized fertilizers based on soil nutrient variability and farmer's perception in South Sumatra rice farming. Based on the above problems, this study aimed to find novel innovation and research of subsidized fertilizers based on soil nutrient variability and farmer's perception in rice farming.

\section{Methods}

This research has been conducted in the province of South Sumatra. Determining the location was done intentionally purposive with the consideration that the research sites are ricefields and rice farming as main income for farmers. This study uses a completely randomized design with four natural treatments 


\section{Jurnal Ekonomi Pembangunan, 18 (1), 2017, 50-63}

and five replicates. The natural treatments consist of technical irrigated ricefield (TR, used as control); rainfed ricefield ( $\mathrm{RR})$; lebak ricefield (LR); tidal ricefield (DR). Composite soil samples were taken and completely analyzed in the laboratory. The data were analyzed using a one-way ANOVA and Tukey HSD Test at the 5\% significance level. Tukey's test will be able to analyze and compare the mean values of chemical properties differences of soils compared with one another. Socio-economic data (purposive sampling) were collected with questionnaires to the respondents. The data obtained were processed in descriptive tabulation and analysis. The data results are analyzed by using the functions of multiple linear regression. To bring the production cost function, then the data was analyzed by using a cubic regression function.

\section{Results And Discussions}

Results and discussion of the research will focus on four important aspects, namely implementation condition of subsidized fertilizer, soil nutrient variability analyses of soil typology, common perception of farmers on the subsidized fertilizer, the HET of subsidized fertilizers, and finding new innovation based on subsidized fertilizers.

\subsection{Implementation Condition Subsidized Fertilizer}

Subsidized fertilizer consist of fertilizers of Urea, SP36, NPK (compound fertilizer) and organic fertilizer. The subsidized fertilizer implementation in South Sumatra is fully conducted on the basis of the Minister Regulation of Agriculture (Permentan) and the Minister Regulation of the Trade (Permendag). Permentan Decree Nr 05/2009 is dealing with the allocation and the HET of subsidized fertilizer for agricultural sector and Permendag Decree nr 7/2009 regulates the procurement and distribution of subsidized fertilizer.
Fertilizer belongs to the groups of commodity and controlled by the Government. The proposal of fertilizer needs by farmers is determined by RDKK (definitive plan of group needs) and farmers as a member of RDKK is based on cultivated land size. Fertilizer paid by farmers are the HET prices, which the prices for fertilizer sales in cash and stated by the Permentan Decree Nr 05/2009 that covering fertilizers of urea, SP36, ZA, NPK and organic fertilizers. Generally fertilizer subsidy have shown positive impact on rice production and productivity as well as farmer's income. However the Permentan Decree Nr 05/2009 and the Permendag Decree Nr 7/2009 do not regulate in details about the specific locations especially relating to the natural conditions, for example the level of regional soil variability of ricefields, rice production, land productivity and common accessibility for farmers (especially the presence of dams, water gates, pump water, infrastructure of street, local retail and others).

Problems of subsidized fertilizer policy are not able to guarantee the fertilizer availability for farmers. Planning the amount of fertilizer needs by farmers is not be entirely accurate and optimal, that causes the distribution of subsidized fertilizer does not meet the target according to Permentan Decree Nr 05/2009 and the Permendag Decree Nr 7/2009. Farmers, who cultivate land less than 0.50 ha, only receive about $40 \%$ of total subsidies and the majority of farmers (possibly over 90\%) are to buy subsidized fertilizer at a price higher than the HET prices. Scarcity case of fertilizers (especially Urea) occurs as a repeated phenomenon almost every year. This is due to the price increase at the farm level, which is far above the HET price. We realize that the problem of subsidized fertilizer as described above is likely complex, thus on this occasion the author just wanted to analyze the relationship of soil nutrient variability, farmer's perception and to find new innovation of subsidized fertilizers in rice farming. 
Avalaible online at http://journals.ums.ac.id

Jurnal Ekonomi Pembangunan, 18 (1), 2017, 50-63

Table 1. Variability of ricefields based on soil typology

\begin{tabular}{|c|c|c|c|c|}
\hline Parameter & $T_{R}^{* * /}$ & $\mathbf{R R}$ & LR & DR \\
\hline \multicolumn{5}{|c|}{ Geology and Geomorphology } \\
\hline Location (District) & OKUT & OKI & OI & Banyuasin \\
\hline Parent material & Granite & Sandstone & Sediment & Alluvium \\
\hline Impermeable layers & available & no & no & no \\
\hline Nutrient loss & minimum & high & high & high \\
\hline \multicolumn{5}{|c|}{ Hydro topography } \\
\hline Water source & Irrigation & Rain & River/rain & River/sea \\
\hline Flooding Type & man-made & natural & natural & natural \\
\hline Water surplus & Always available & Sept to Des & Sept to Des & Oct to Jan \\
\hline Water shortage & Always available & April-Augt & April-Augt & April-Augt \\
\hline \multicolumn{5}{|c|}{ Landuse pattern } \\
\hline Planting season/year & $\begin{array}{l}\text { Dec-Mar } \\
\text { Apr-July } \\
\text { 2-3 times }\end{array}$ & $\begin{array}{l}\text { Apr-Sept } \\
1 \text { time }\end{array}$ & $\begin{array}{l}\text { Apr-Sept } \\
1 \text { time }\end{array}$ & $\begin{array}{l}\text { Apr-Sept } \\
1 \text { time }\end{array}$ \\
\hline Rice variety & Ciherang & Pegagan & Ciherang & Gogo \\
\hline Fertilizer dose & various & various & various & various \\
\hline \multicolumn{5}{|c|}{ Management of rice farming } \\
\hline Land size (ha) & 0.88 & 0.88 & 1.20 & 2.11 \\
\hline Rice farming & intensive & less & less & enough \\
\hline \multicolumn{5}{|c|}{ Yields and productivity } \\
\hline $\begin{array}{c}\text { Production } \\
\text { (ton MDG/year) }\end{array}$ & 13.09 & 5.22 & 5.01 & 3.93 \\
\hline $\begin{array}{c}\text { Productivity } \\
\text { (ton MDG/ha/year)*/ }\end{array}$ & 14.87 & 5.93 & 4.17 & 1.86 \\
\hline
\end{tabular}

Note: */ MDG (Milled Dry Grain); **/ TR (Technical irrigated ricefield); RR (Rainfed ricefield); LR (Lebak ricefield); DR (Tidal ricefield)

\subsection{Soil Nutrient Variability of Soil Typology}

Each ricefield showed dominantly the variability of different soil nutrients, which can be analyzed from its causing factors, i.e. in the aspects of geology and geomorphology, hydro topography, patterns of land use Table 1 and Table 2. Geology and geomorphology reflects the variability of the parent material and relief forms, which cause the initial formation of soil nutrient variability (it can be detected from the variety of soil texture and structure. Soil nutrient variability caused by this process is named as Lithovariance.

Hydro topography affects soil nutrient variability in processes involving the soil formation and development, which took place not uniform in the soil profile, for example, the process of transformation and translocation of elements or soil fractions (clay migration). This variability can be detected through various profile description. The variability is dominantly determined by this factors called Pedovariance. This variability is divided into two groups, namely by lateral interflow of nutrients (IntraTopovariance), while soil nutrient variability is driven by erosion process called as External Topovariance.

The pattern of land use, namely the spread of crops and land use patterns are different and uneven, obviously a major influence on the functions in the soil either caused by 


\section{Jurnal Ekonomi Pembangunan, 18 (1), 2017, 50-63}

varying absorption or plant litter returns. Soil nutrient variability induced by these factors is called Phytovariance. Fertilization applications, namely the existence of uneven fertilization in an area well done intentionally or unintentionally would cause soil variability named as Anthropovariance.

All above factors causing soil nutrient variability do not play alone, but rather together and form a very complex variability in the time and space dimension. Soil nutrient variability is not only led to divergent attributes of the land alone, but also affects the soil function in the ricefields, in particular the crop appearance that grow on it and leaching the agrochemical elements. External functions may be indicated by an attribute in the soil surfaces, but the absolute calibration is required.

Soil Acidity (pH values), the results of analysis of variance showed that applying subsidized fertilizer affects soil $\mathrm{pH}$ significantly different, technical irrigated ricefield was higher and significantly different compared with rainfed ricefield and lebak ricefield and was very significantly different compared with tidal ricefield. Rainfed ricefield was not significantly different with lebak ricefield and showed significant difference with tidal ricefield, so it can be concluded that subsidized fertilizer provides positive increase of soil $\mathrm{pH}$ and the highest increase was showed by technical irrigated ricefield.

Table 2. Average C-organic, total N, available P and K in topsoils and Tukey Tests*/

\begin{tabular}{cccccc}
\hline \multirow{2}{*}{$\begin{array}{c}\text { Soil typology } \\
\text { (Ricefields) }\end{array}$} & $\mathbf{p H} * * /$ & $\mathbf{C}_{\text {org }}(\%)$ & $\mathbf{N}_{\text {total }}(\%)$ & $\mathbf{P}_{2} \mathbf{O}_{5}(\mathbf{p p m})$ & $\mathbf{K}_{2} \mathbf{O}(\mathbf{p p m})$ \\
\cline { 2 - 5 } & $5.89^{\mathrm{a}}$ & $2.78^{\mathrm{a}}$ & $0.25^{\mathrm{a}}$ & $22.99^{\mathrm{a}}$ & $21.56^{\mathrm{a}}$ \\
\hline Technical irrigated (TR) & $5.21^{\mathrm{b}}$ & $2.12^{\mathrm{b}}$ & $0.22^{\mathrm{b}}$ & $15.45^{\mathrm{b}}$ & $16.77^{\mathrm{b}}$ \\
Rainfed (RR) & $5.03^{\mathrm{b}}$ & $2.88^{\mathrm{a}}$ & $0.24^{\mathrm{ab}}$ & $17.11^{\mathrm{b}}$ & $15.63^{\mathrm{b}}$ \\
Lebak (LR) & $4.98^{\mathrm{c}}$ & $2.69^{\mathrm{a}}$ & $0.23^{\mathrm{b}}$ & $13.09^{\mathrm{b}}$ & $11.91^{\mathrm{b}}$ \\
Tidal (DR) & &
\end{tabular}

Source: Primary data (2016).

Explanations: */ Soil assessment is based on the general nature of tropical soils. **/ Means values in the each column with the same superscript letters do not differ significant at significance level of $5 \%$

Organic C showed slightly different pattern, where almost all ricefields have given positive respond to increase in soil organic $\mathrm{C}$, except to rainfed ricefield due to high leaching process. The highest respond was given by lebak ricefield. High organic $\mathrm{C}$ in lebak ricefield was probably influenced by water dynamics which accumulate some organic $\mathrm{C}$ in lebak ricefield.

Subsidized fertilizer applied could improve the availability of soil NPK nutrients almost in all ricefields. Technical irrigated ricefield has the highest average in the supply of soil NPK nutrients and responded significantly different compared to other ricefields. This proved that the higher dose of subsidized fertilizer of NPK would increase also higher the available nutrients of NPK.
All factors causing soil nutrient variability will improve the variability of ricefield. The method for determining soil nutrient variability is to make the mapping units of soil nutrient range for each soil typology. The Government does not take this natural phenomena into account in determining how much fertilizer subsidy should be given to farmers. The fertile ricefields and poor ricefields get the same doses of fertilizers. Thus for fertile ricefields meaning subsidized fertilizer is useless because act of fertilization becomes ineffective and inefficient, in other case the poor ricefields need more fertilizer as recommended by the Government. In other words, we are taking about suitability and carrying capacity of ricefields to produce rice in the fields. 


\section{Jurnal Ekonomi Pembangunan, 18 (1), 2017, 50-63}

\subsection{Common Perception of Farmers on the Subsidized Fertilizer}

Perceptions of farmers on subsidized fertilizer were analyzed from the closed questionnaire asked to respondents. The perceptions of farmers in general are highly varied and grouped into five components, namely:

a. Use of subsidized fertilizer for not subsidies The use of subsidized fertilizer for not subsidies was so often found in the fields. The subsidy policy of fertilizer is basically for increasing the welfare of farmers and sustainable rice farming, however subsidized fertilizer was utilized for rubber, oil palm or other horticultural crops. Thus scarcity of subsidized fertilizer in the domestic market is common phenomena which is due to seepage of subsidized fertilizer from the market to non-subsidized market. This occurred due to weak monitoring system of fertilizer application, which was established by the Government. Approximately the inaccuracy due to this factor ranged $64-75 \%$.

b. Calculation of subsidized fertilizer needs Calculation of fertilizer needs is less appropriate for the unit of the planting area $(\mathrm{kg} /$ ha). Total plan of fertilizer needs set by the Government is generally lower than the actual area planted, so the amount of fertilizer demand is always more than is allocated. In addition, the calculation of inaccuracy is because fertilizer needs only approach is based on the predicted approach (rough estimates) only, not based on the analysis of soil and plant tissue as well as conditions of ricefields. It is estimated that the calculation of the need for fertilizers ( $\mathrm{kg} / \mathrm{ha}$ ) misses lower by about $43-61 \%$.

c. Subsidized fertilizer application in rice farming

Most of farmers did not apply approach of balanced fertilization. Around $64 \%$ of farmers mentioned that Urea belongs to very important fertilizer, thus they have used Urea dominantly beyond its recommended dose.
In the calculation of fertilizer subsidy, the recommended Urea dose by the Government is around $250 \mathrm{~kg}$ Urea/ha, but in practical cases they fertilized their soils with Urea with dose in the range of 300-450 kg Urea/ ha because they believed that Urea belongs to a major and absolutely necessary fertilizer, while other fertilizers (such as SP36 and $\mathrm{KCl})$ are only a complement fertilizer, so it is often found that some farmers did not use the SP36 and $\mathrm{KCl}$ because the price is relatively expensive. Fertilizing Urea excess recommendation will trigger the excessive vegetative growth of rice and generative growth will be depressed, it will eventually affect rice plants fall down due to wind blow and flowing water, as the impact that the rice yield will decrease.

d. Irregular planting pattern

Farmers are indiscipline in planting pattern, which is strongly influenced by uncertain climate. For example, farmers usually plant rice twice on technical irrigated ricefields, when there is still a sufficient water supply in Gadu (MK II), thus they generally cultivate rice again, resulting in a huge demand for subsidized fertilizers. Beside that fertilizer demand in horticultural crops is also very difficult to quantify. The types of commodities were planted on uncertain and ever-changing according to market demand. It is observed that inaccuracy due to irregular planting pattern is in the range $26-59 \%$.

e. Cultivated land size

Ownership of soils by farmers is generally narrow ( $<0.5 \mathrm{ha})$ and also led to the use of fertilizers that are converted into a single ha to be very high. Often it happens that subsidized fertilizer was evenly for each farmer, the farmer's acreage is different, so that there is excess fertilizer in a narrow planting area, and thus subsidized fertilizer would be sold or applied it all to the ricefield. At the farmer who owns land $>1.0$ ha, very often happens that subsidized fertilization was 


\section{Jurnal Ekonomi Pembangunan, 18 (1), 2017, 50-63}

applied below the recommended dose. It is estimated inaccuracy due to this factor is in the range $46-71 \%$.

The general perception of farmers to subsidized fertilizer can cause some conflicts of interest. The difference in interest is determined as normal, unavoidable and natural occurrence. In some cases, it is wanted by the Governmental system to counterbalance the Government policy. Therefore, an integrated approach is needed to make it harmonious and balanced condition. The occurrence of interest differences is mostly determined by the difference in two components, namely the adequacy of information and information resources. The information delivered to farmers has to be true, thus it is expected that perception of farmers will become more positive

Table 3. Cubic regression analysis based on the typology of ricefields

\begin{tabular}{ccc}
\hline $\mathbf{N r}$ & Ricefields & Cubic equations \\
\hline 1 & Technical Irrigated Ricefield & $\mathrm{Y}=53,877.79+887.71 \mathrm{Q}-0.0021 \mathrm{Q}^{2}+0.0000003762 \mathrm{Q}^{3}$ \\
2 & Rainfed Ricefields & $\mathrm{Y}=417,375.42+765.91 \mathrm{Q}-0,023 \mathrm{Q}^{2}+0.000000502 \mathrm{Q}^{3}$ \\
3 & Lebak Ricefields & $\mathrm{Y}=327,659.78+8669.01 \mathrm{Q}-0.020 \mathrm{Q}^{2}+0.000000459 \mathrm{Q}^{3}$ \\
4 & Tidal Ricefields & $\mathrm{Y}=409,998.54+980.99 \mathrm{Q}-0.085 \mathrm{Q}^{2}+0.00000398 \mathrm{Q}^{3}$ \\
\hline
\end{tabular}

Note: Y (total cost of rice production); Q (rice production)

Table 4. Variable costs and the real and eligible costs of subsidized fertilizer

\begin{tabular}{|c|c|c|c|}
\hline $\mathrm{Nr}$ & Cost components & $\begin{array}{c}\text { Real cost } \\
\text { (Million Rp/year) }\end{array}$ & $\begin{array}{c}\text { Eligible costs } \\
\text { (Million Rp/year) }\end{array}$ \\
\hline \multicolumn{4}{|c|}{ Technical irrigation Ricefields } \\
\hline 1 & Variable costs & 96.89 & 64.89 \\
\hline \multirow[t]{4}{*}{2} & Fertilizer costs (16.71\%) & 16.19 & 10.84 \\
\hline & Urea $(40.21 \%)$ & 6.82 & 4.56 \\
\hline & $\mathrm{NPK}_{\text {Phonska }}(45.01 \%)$ & 7.29 & 4.88 \\
\hline & $\mathrm{KCl}(14.78 \%)$ & 2.39 & 1.60 \\
\hline \multicolumn{4}{|c|}{ Rainfed Ricefields } \\
\hline 1 & Variable costs & 90.97 & 75.00 \\
\hline \multirow[t]{3}{*}{2} & Fertilizer costs $(13.39 \%)$ & 12.18 & 10.04 \\
\hline & Urea $(38.01 \%)$ & 4.63 & 3.82 \\
\hline & $\mathrm{NPK}_{\text {Phonska }}(61.99 \%)$ & 7.55 & 6.22 \\
\hline \multicolumn{4}{|c|}{ Lebak Ricefields } \\
\hline 1 & Variable costs & 70.23 & 60.41 \\
\hline \multirow[t]{4}{*}{2} & Fertilizer costs (12.97\%) & 9.08 & 7.81 \\
\hline & Urea $(53.83 \%)$ & 4.89 & 4.20 \\
\hline & $\mathrm{NPK}_{\text {Phonska }}(35.34 \%)$ & 3.21 & 2.76 \\
\hline & $\mathrm{KCl}(7.83 \%)$ & 0.71 & 0.61 \\
\hline \multicolumn{4}{|c|}{ Tidal Ricefields } \\
\hline 1 & Variable costs & 98.84 & 35.49 \\
\hline \multirow[t]{3}{*}{2} & Fertilizer costs $(20.94 \%)$ & 20.70 & 7.43 \\
\hline & Urea $(77.17 \%)$ & 15.97 & 5.74 \\
\hline & $\mathrm{KCl}(22.83 \%)$ & 4.73 & 1.70 \\
\hline
\end{tabular}

Source: Primary data (2016). 


\subsection{The HET of Subsidized Fertilizer}

The HET was regulated by the official Government and influence on the number of subsidized fertilizer use is presented in Table 3. The number of subsidized fertilizer use will greatly affect the rice production and on the end result will affect the income of farmers directly. Some responds of farmers to the high HET, the farmers reduce the use amount of fertilizer compared to maintain the amount of fertilizer because of limited capital farming. The data obtained are presented in a cubic equation which indicates the dependent variable $(\mathrm{Y})$ is the total cost of rice production and the independent variable $(\mathrm{X})$ is the rice production of ricefields.

Table 4 illustrates that the HET of subsidized fertilizer to reach the hands of farmers is greater than a predetermined HET by the Government. This is due to a lack of The Government control and monitoring on the part of retailers. The HET of subsidized fertilizer is eligibly received by farmers in each soil typology of ricefields and summarized in Table 5.

The fertilizer cost for each fertilizer type used on the percentage of each type of fertilizer costs to variable costs of rice farming. Prices in the hands of farmers will be compared with eligible HET received by farmers, with the ratio of the real variable costs and variable costs derived from cubic regression formula. Thus it is obtained the eligible HET received by farmers and it is tabulated in Table 5.

In the technical irrigation ricefields, from the mathematical calculations is calculated that variable costs in the field is Rp 96.89 million, while the variable costs were obtained from the cubic regression is $\mathrm{Rp} 64.89$ million, then there is a difference of $\mathrm{Rp} 32$ million. The cost of fertilizer give a value of $16.71 \%$ of the variable costs and for the three fertilizers used in the ricefields, percentage of each of the total cost of the use of fertilizers are urea fertilizer costs amounted to $40.21 \%, \mathrm{NPK}_{\text {Phonska }}$ costs amounted to $45.01 \%$ and the cost of $\mathrm{KCl}$ fertilizer by $14.78 \%$. The HET of subsidized fertilizer is lower than the real HET of subsidized fertilizer, although this is the Urea price is in the hands of farmers has equaled HET of subsidized fertilizer that has been set by the Government. $\mathrm{KCl}$ fertilizer which is a nonsubsidized fertilizer intentionally can be analyzed in order to become reference for the government to make fertilizer $\mathrm{KCl}$ as fertilizer subsidy. The difference of the real HET and the eligible HET received by farmers is $33.03 \%$.

In the rainfed ricefields, the real variable costs in the field was around Rp 90.97 million while variable costs obtained from the cubic regression was only $\mathrm{Rp} 75.00$ million. The cost of fertilizer give a percentage of $13.39 \%$ of the variable costs and for both fertilizers used in this ricefields, the percentage of each of the total cost of the use of fertilizers are Urea fertilizer costs amounted to $38.01 \%$ and the cost of $\mathrm{NPK}_{\text {Phonska }}$ was $61.99 \%$. The real variable costs would be compared with variable costs of regression results, in order to obtain an eligible HET received by farmers. From the comparison of the real price and eligible HET received by farmers, it can be seen that the difference of the real HET and the eligible HET received by farmers is $17.56 \%$.

In the lebak ricefields, total variable costs in the field amounted to $\mathrm{Rp} 70.23$ million, while variable costs obtained from the cubic regression is $\mathrm{Rp} 60.41$ million. The fertilizer costs were around $\mathrm{Rp} 9.08$ million (12.97\% of the variable costs). The percentage of each fertilizer (for Urea, $\mathrm{NPK}_{\text {Phonska }}$ and $\mathrm{KCl}$ ) was $53.83 \%$; $35.34 \%$ and $7.83 \%$ respectively. The difference of the real HET and the eligible HET received by farmers is $13.98 \%$.

In the tidal ricefields, the real variable costs in the field was around Rp 98.84 million while variable costs obtained from the cubic regression was $\mathrm{Rp} 35.49$ million. The cost of fertilizer give a percentage of $20.94 \%$ of the variable costs and for both fertilizers used in this ricefields, the percentage of each of the total cost of the use of fertilizers were Urea fertilizer costs amounted to $77.17 \%$ and the cost of $\mathrm{KCl}$ was $22.83 \%$. This occurs because although the rice 


\section{Jurnal Ekonomi Pembangunan, 18 (1), 2017, 50-63}

price received by farmers is high enough, but the soil productivity is very low if it is compared to the other soil productivities. In determining the HET of subsidized fertilizer, the Government should consider the growing season each year cycle, soil productivity and available infrastructure in fields. The difference of the real HET and the eligible HET received by farmers is $64.09 \%$.

Table 5. The real HET and eligible HET received by farmers (Rp/kg)

\begin{tabular}{ccccccccc}
\hline \multirow{2}{*}{ Fertilizer } & \multicolumn{2}{c}{$\begin{array}{c}\text { Technical } \\
\text { irrigation }\end{array}$} & \multicolumn{2}{c}{$\begin{array}{c}\text { Rainfed } \\
\text { Ricefields }\end{array}$} & Lebak Ricefields & \multicolumn{2}{c}{ Tidal Ricefields } \\
\cline { 2 - 9 } & Real & Eligible & Real & Eligible & Real & Eligible & Real & Eligible \\
\cline { 2 - 9 } & 1900 & 1272 & 2400 & 1979 & 2000 & 1720 & 2100 & 754 \\
Urea & 2600 & 1741 & 2990 & 2465 & 2400 & 2064 & na* & na \\
NPK $_{\text {Phonska }}$ & na*/ & na & na & na & 3100 & 2667 & na & na \\
KCl & 4200 & 2813 & na & na & na & na & 4100 & 1472 \\
$\mathrm{~A}^{* * /}$ & \multicolumn{3}{c}{33.03} & \multicolumn{3}{c}{17.56} & & \\
\hline
\end{tabular}

Note: $n a^{*} /$ not available data; $\mathrm{A}^{* *} /$ the difference of the real HET and the eligible HET received by farmers $(\%)$.

\subsection{Finding Novel Innovation and Research based on Subsidized Fertilizers}

If we look at thorough the relatively comprehensive problems of subsidized fertilizer, not just only from the aspect of the Government, distribution, but also at the rice farming level as well as the natural soil variability, thus this paper is to find out novel innovation and research of subsidized fertilizers based on soil nutrient variability and farmer's perception in rice farming. The emphasis of the study focused only on the basis of the soil nutrient variability and farmer's perception, so that we can try to find a bottom-up approach of subsidized fertilizer. Such an approach can be specific locations, more flexible and involving the university as a thinktank. The main goal of this novel innovation can be categorized into two approaches, which target short-term approach and a long-term approach.

\section{a. Short-Term Approach}

Subsidized fertilizer target in short-term is intended only for how to apply fertilizer in rice farming effectively, efficiently and sustainably. So the short-term emphasis is how the problem resolution of subsidized fertilizer. This needs to be addressed, given the high demands on the amount of fertilizer, fertilizing properly, impartial, just, economical, and environmentally sound. So that needs completion wise to dose or amount of fertilizer, especially in the agricultural area with a ricefield variability that cannot be avoided.

Ricefield variability may include variability of soil nutrients, minerals, organic matter and waters. So ricefield variability itself when examined from land fertilization approach can be seen as an opportunity or a threat of rice farming. Having regard to the variability of ricefield, it will be able to optimize all the research and optimization concepts fertilizing land that includes components such as:

1) Research needs of soil nutrients per ha based on diagnosis data

2) The conversion calculation of soil nutrients in the form of fertilizers per ha

3) Fertilizer amount per activity or area, in accordance with the extent of agricultural land

4) The selection of the appropriate mineral fertilizers based on the needs of plants, soil properties, and analysis of cultivated land

5) Taking into account the feasibility of the fertilizer price based on shape and different soil nutrient availability and on the basis of the nutrient content in different fertilizers 


\section{Jurnal Ekonomi Pembangunan, 18 (1), 2017, 50-63}

6) Instructions of fertilizer utilization based on time and in accordance with the phases of plant growth

7) Instructions for distributing fertilizer with due regard to effectiveness, minimize nutrient leaching and erosion processes

8) Applying fertilizer balance calculation and mineral fertilizer needs

9) Calculation of fertilization in integrated farming activities (through animal feed) and a chain of nutrient dynamics

10) Balance of nutrients to each area or for the entire area and supervision fertilization to come.

Planning fertilization based on the above approach is highly dependent on the diagnosis of crop needs and nutrient uptake by plants. Conventional fertilizer applications, usually based on the analysis of soil samples or sample composites leaf analysis. Then the results of the analysis carried out conversion of nutrients to the amount of fertilizer to be administered and implemented fully, regardless of their ricefield variability. Whereas in fact, fertilization should be done vary depending on location. Very high variability of Ricefield clearly illustrate the variability of the nutrient is also high. Therefore, based on the fertilizer division ricefield rate variability (in different areas), and requires special diagnosis. This standard process reflects the way fertilization fair and environmentally sound.

In the early stages, diagnosis fertilization based on local needs are of course expensive and require research and extension as well. One approach that might be done in addition to nutrient analysis provided is with the prediction by the principle of pedo-transfer functions. Factors in these functions wherever possible factors include land that is constant (e.g. percentage of clay and humus). The process is relatively easy and inexpensive, with power relatively high accuracy.

The possibility of other approaches are also easily is based on the distribution of fertilizers according to the previous harvest. Through research yields allow for differences in the area of production can be examined for the entire area, with the assumption that the difference is smaller than the yields based on different doses of fertilizer.

Fertilization for the next planting period can be set, that is by increasing doses of fertilizer on areas whose production a little, or a reduction in the dose of fertilizer on areas whose production has exceeded the optimum point. This logic uses the assumption that other factors in a constant state. If the interpretation is done without regard to the above assumptions, the computer approach will result in more errors dose of fertilizer. It can be concluded that the variability into account differences in the level of ricefield locally, is an appropriate alternative in the application of fertilizer, but in practice it is not as easy as what is described above. To arrive at the above process, then this approach requires the availability of skilled soil scientist and computer devices were adequate.

\section{b. Long-Term Approach}

Long-term research goals of fertilization do not only solve the short-term problems, trials, but includes the mission and vision of what would be obtained in the business of subsidized fertilization. Because research is a long-term fertilization intellectual investment (intellectual capital), then it is very difficult results were obtained in the form of research reports, annual reports or any other time-related reporting and targets and are very vulnerable to funding cuts. Therefore, many private companies consider that these activities are not economically, consequently patterns such research is not done. However, there are at least six important reasons why the study of long-term fertilization is absolutely necessary because these studies were able to:

1) Fertilization Technology by Soil Science Knowledge

Soil science knowledge is the main supporter of the development of fertilization technology. 


\section{Jurnal Ekonomi Pembangunan, 18 (1), 2017, 50-63}

Based on the fact that fertilization technology has led to the formation of patent rights. In 2000-2010, the average references per patent to scientific papers about $15-20 \%$ per year. Overall, the average number of references per patent on the ground research increased over the past two decades. The existence of a strong relationship in reference to scientific papers showed a strong link between fertilization technologies with knowledge of Soil Science. Each patent issued by the US Company had an average of 5-10 references of the scientific articles (Galperin et al., 2017). Their references Soil Science in fertilization technology patent indicate something sensitive about relations between the Soil Science with fertilization technology.

2) Media Cooperation between Scientists, Technocrats and Bureaucrats

Long-term studies will facilitate the establishment of media cooperation and participation between scientists, technocrats and bureaucrats from outside the institution conducting the research. Unfortunately, this goal is difficult to be isolated, measured and understood by private companies. A lot of money invested each year by public institutions for research. But $>80 \%$ of the results of such research be used by the private sector directly. If the private manager asked how much of the technology obtained from outside or public institution (Government), they tend to be condescending and assume nothing. When traced step by step the technologies they use, it turns out almost all from outside the company. How it works thus causing the technology they have unsustainable and difficult to develop. Although the private sector is able to do your own research, but the private sector has no long-term research orientation that will help save the company from collapse. People who are able to design and find the technology needed by the private sector is active researcher. To get results with a satisfactory quality, then the private sector should offer competitive basis to researchers study.

3) Generating New Sources of Wealth Long-term fertilization research capable of generating new sources of wealth through new product or process approach, simultaneously give rise to new business opportunities, new industries and even capable of transferring a society, such as the discovery of foliar fertilizer and phosphate fertilizer solvent. Realizing the source of new wealth is not simple, so research fertilization needs to be managed very well. The privately held company that has been well aware of the benefits of such research and has been running more than 10 years, should now be in a better position established and have benefited. For example, research conducted by PT. GMP about the discovery of sugarcane varieties and its relationship with a particular dose of fertilizer.

4) The Great Invention of Ownership Value (Patent)

Patent rights or royalties research results can only be implemented through long-term research, for example, invented and patented bacterial phosphate solvent. Two-thirds of scientific papers published by the public sectors (laboratory, University, research) in biotechnology has become a reference in the process of patenting. Each of the average patent reference 20 scientific papers. Public sector parties have been sharing $82 \%$ of the job done and $18 \%$ of private companies, but patent rights mostly carried out by foreign private company.

5) Research Funding

Product offerings to consumers, it is a private company should establish contacts with the development of science, therefore it is very important private companies to participate actively to the science development. Participation science can be done in the 


\section{Jurnal Ekonomi Pembangunan, 18 (1), 2017, 50-63}

form of conferences, seminars and scientific workshops. So that private companies can put themselves at the forefront of product development and scientific marketing. Private companies conduct basic research aimed not only to motivate the development of new products, but more importantly to study the development of products from other private companies. Furthermore, the private company can produce a variety of products offered in the company profile (books of company) which will facilitate customers gain a positive image of the product and the company itself.

Funding research can be done through longterm research that can produce varied and able to increase the price of basic products. Private companies that have patents and long-term research is able to increase by $35 \%$ the price of basic products on the market compared with companies with no patent and no long-term research. In other words, long-term research funding will be very valuable and useful as the financing of such research would be very easy to be covered by product diversification and an increase in the base price. As an example of a company Potash \& Phosphate Institute of Canada with its long-term research is able to offer many kinds of nature $\mathrm{P}$ fertilizer products and able to maintain and even increase the price of basically all over the world.

6) Establishing and Maintaining Professionals of Researchers

Long-term fertilization research were able to establish and maintain a professional and highly qualified researchers for the development of research capability is determined by the presence of long-term research and the availability of funds. Through long-term research, it takes no special charges in the formation of a reliable and professional researchers, particularly on products with a high market value.

\section{Conclusions}

Based on the above results and discussion, same conclusions can be drawn as follows:

a. The fertilizer uniformity on varied ricefields was a big failure because it causes fertilization becomes ineffective, inefficient and unsustainable

b. The main causes of soil variability is the geomorphogenesis process, pedogenesis, interflow flow, distribution of vegetation and land use patterns, and the application of fertilizer

c. Ricefield variability is targeted for fertilization optimization in terms of dosing, balance and methods of fertilization

d. The perception of farmers to subsidized fertilizer can cause some conflict of interest, which is determined as normal occurrence, unavoidable and natural.

e. Short-term research target of fertilization is how fertilization in the field effectively, efficiently, and sustainably, whereas long-term target is to generate new sources of wealth, fertilization technology based on knowledge of soil science, forming professional researcher, the great inventions of the ownership value (patent), and cooperation media between scientists, technocrats and bureaucrats as well as research funding.

\section{Acknowledgement}

Authors would like to say many thanks to the Sriwijaya University that has provided research grants. Thanks were also given to the staffs of the Faculty of Agriculture Sriwijaya University who have helped in the conduct of research in the field. More specific thanks are given to undergraduate and postgraduate students and local people who have helped in collecting data in the field.

\section{References}

Armanto, M.E., M.A. Adzemi and E. Wildayana. 


\section{Jurnal Ekonomi Pembangunan, 18 (1), 2017, 50-63}

(2013), "Understanding Characters of Compound Fertilizer and Its Alternative Uses," Bulletin Agroteks, UMT Malaysia. Bil 5(2013): 3-7.

Banful, A.B. (2011), "Old Problems in the New Solutions? Politically Motivated Allocation of Program Benefits and the "New" Fertilizer Subsidies," World Development. Vol. 39(7); 1166-1176.

Comtea, I., F. Colinc, O. Grünberger, S. Follainc, J.K. Whalena, and J.P. Calimane. (2013), "Landscape-Scale Assessment of Soil Response to Long-Term Organic and Mineral Fertilizer Application in an Industrial Oil Palm Plantation, Indonesia". Agriculture, Ecosystems and Environment. Vol 169; 5868.

Druilhe, Z. and J. Barreiro-Hurlé. (2012), "Fertilizer subsidies in sub-Saharan Africa," ESA Working Paper No. 12-04. Rome, FAO.

Ellis, F. and D. Maliro. (2013), "Fertiliser Subsidies and Social Cash Transfers as Complementary or Competing Instruments for Reducing Vulnerability to Hunger: The Case of Malawi”. Development Policy Review. Vol 31(5); 575-596.

Galperin, H. and M.F. Viecens. (2017), "Connected for Development? Theory and Evidence about the Impact of Internet Technologies on Poverty Alleviation”. Development Policy Review. Vol 35(3); 315-336.

Inoue, S., T. Okae, and K. Ashi. (2015), "Rice Policy Trends in Southeast Asian Countries: Thailand, Vietnam and Indonesia”. PRIMAFF Review. Vol 66(7); 4-5.

Kariyasa, K., M. Maulana and S. Mardianto. (2004), "Usulan Tingkat Subsidi dan Harga Eceran Tertinggi (HET) yang Relevan serta Perbaikan Pola Pendistribusian Pupuk di Indonesia", Analisis Kebijakan Pertanian, Vol 2(3); 227-287, Pusat Penelitian dan Pengembangan Sosial Ekonomi Pertanian,
Bogor.

Osorio, C.G., D.E. Abriningrum, E.B. Armas and M. Firdaus. (2011), "Who is Benefiting from Fertilizer Subsidies in Indonesia?" Policy Research Working Paper 5758, Poverty Reduction and Economic Management Unit, East Asia and Pacific Region, the World Bank

Rachman, B. and T. Sudaryanto. (2010), "Impacts and Future Perspectives of Fertilizer Policy in Indonesia". Analisis Kebijakan Pertanian. Vol. 8(3); 193-205.

Rashid. S., N. Tefera, N. Minot and G. Ayele. (2013), "Can Modern Input Use be promoted without Subsidies?" An Analysis of Fertilizer in Ethiopia. Agricultural Economics. Vol. 44(6); 595-611.

Ricker-Gilbert, J., T.S. Jayne and J.R. Black. (2009), "Does Subsidizing Fertilizer Increase Yields? Evidence from Malawi". Selected Paper prepared for presentation at the Agricultural \& Applied Economics Association 2009 AAEA \& ACCI Joint Annual Meeting, Milwaukee, Wisconsin, July 26-29, 2009

Warr, P. and A.A. Yusuf. (2014), "Fertilizer Subsidies and Food Self-Sufficiency in Indonesia". Agricultural Economics. Vol 45(5); 571-588.

Wildayana, E. (2014), "Formulating Oil Palm Investment Decision in Tidal Wetlands of South Sumatra, Indonesia". Journal of Wetlands Environmental Managements. Vol $2(2) ; 30-36$.

Wildayana, E. (2015), "Formulating Rice Fields Conversion Control to Oil Palm Plantations in Tidal Wetlands of South Sumatra, Indonesia”. Journal of Wetlands Environmental Managements. Vol 3(2); 72 78.

Wildayana, E., D. Adriani and M.E. Armanto. (2017), "Livelihoods, Household Income 
Jurnal Ekonomi Pembangunan, 18 (1), 2017, 50-63

and Indigenous Technology in South Sumatra Wetlands". Sriwijaya Journal of Environment, Vol. 2(1); 23-28.

Wildayana, E., M.S. Imanudin, H. Junedi, M. Zuhdi and M.E. Armanto. (2016), "Parameters Affecting Household Income Diversity of Farmer's Tribes in South Sumatra Tidal Wetland". Sriwijaya Journal of Environment, Vol 1(3); 47-52. 